\title{
SOME ADDITIONAL REMARKS ON THE MASARID WASPS (HYMENOPTERA)
}

\author{
BY J. BEQUAERT \\ Department of Tropical Medicine, \\ Harvard Medical School, Boston, Mass.
}

While my study of the Masaridinæ was going through the press for the June 1929 issue of "Psyche", two important papers have been published dealing with these insects. It seems worthwhile to consider in how far the new information they present agrees with the conclusions I had reached.

A. v. Schulthess' "Contribution to the Knowledge of African Masaridæ" (May 1929, Ann. Mag. Nat. Hist., (10) III, pp. 498-511) contains descriptions of ten new species and one new genus. While it confirms what I had to say about the possibilities of future discoveries in this group, it does not call for any change in the map I gave of the general distribution of these wasps. Masariella (?) testaceopicta v. Schulthess is, I take it, the undescribed species of Jugurtia, from Northern Nigeria, which I mentioned in my paper.

Three of v. Schulthess' new species are placed doubtfully in Masariella, one of them being from North Africa, one from Northern Nigeria, and the third from South Africa. In how far these species are strictly congeneric with the genotype, $M$. alfkeni (R. du Buysson), is impossible to decide, since the mouth-parts are not described. While v. Schulthess rightly doubts that the relative development of the scutellum and postscutellum is sufficient to distinguish between Masaris and Masariella, his statement that "the most important criterion remains the number of the joints of the maxillary palpi (two in Masariella, four in Masaris)," must be due to an oversight. Bradley, who has made the most careful study of the mouth-parts of the Masari- 
dinæ, says that in Masaris the maxillary palpus is "reduced to a single segment represented by a mere tubercle". He was unable to make out that of Masariella, but writes merely that they are "said by Brauns to be two-segmented." It will be noted that the difference is very slight indeed, and, Bradley's opinion notwithstanding, I greatly doubt its value as a generic character. In my recent paper I provisionally placed all the South African species in Masariella and those from the Mediterranean Subregion in Masaris; but it remains to be shown whether this purely geographical segregation is supported by a consistent difference in the mouth-parts or by other valid generic characters. As for the species from Northern Nigeria doubtfully placed in Masariella by v. Schulthess, a careful study of the antennal characters will have to decide whether it is not rather a Jugurtia (of which one species is known from Gambia). The shape of the clypeus I can hardly regard as of generic value.

It may be noted that v. Schulthess now expressly synonymizes his genus Ceramiellus (1922) with Masariella, a course which I had followed in my paper.

The six new species of Quartinia, described by v. Schulthess, are all from South Africa and bring the total number of species of that genus up to 14 ( 8 of them South African).

By far the most interesting addition though is the new genus Quartiniella, proposed for a new species, Q. waterstoni, of the Cape Province, South Africa. This little wasp, $31 / 2 \mathrm{~mm}$. in total length, is unique, not only among the Masaridinæ but among the entire group Diploptera as well, in the reduction of the wing venation. The fore wing has only one closed cubital and one closed discoidal cell. That the single cubital cell corresponds to the true first cubital of the other Diploptera (and not to the combined first and second cubital cells), is reasonably certain from the course of the only recurrent vein which ends a little beyond the apex of the cubital cell (as stated in the text, while the drawing shows it interstitial). Otherwise the genus is said to be closely allied to Quartinia, but the mouth-parts are not described. 
Celonites rugiceps Bischoff, 1928, Abhandl. Naturwiss. Ver. Bremen, XXVII, 1, p. 86, which was overlooked by me at the time, increases the number of species of Celonites of the Mediterranean Subregion to 10.

In discussing the wing venation, I have overlooked one peculiarity of some importance, to which my attention has been called recently in a discussion with Prof. T. D. A. Cockerell. In all the genera of Masaridinæ known to me, the marginal (or radial) cell $(2 d R 1+R 2)$ of the fore wing is more or less truncate at the apex, its extremity being distinctly removed from the costal margin and generally provided with an appendicular vein. As pointed out by Bradley (1922, Univ. of California Publ. Ent., I, No. 9, p. 376), the Masaridinæ share this peculiarity with the Euparagiinæ and Gayellinæ, while a truncate or appendiculate marginal cell is rather exceptional among the remainder of the Diploptera. I have seen it in certain species of Zethus, Labus, Ancistrocerus, Odynerus, Pterochilus, Monobia, and Montezumia, where it occurs rather sporadically, but it never seems to be present in the true social wasps of the subfamilies Ropalidiinæ, Polistinæ, Polybiinæ, Vespinæ and Stenogastrinæ.

Although not of absolute value, the shape of the marginal cell may afford some help in tracing the affinities of the fossil insects that have been referred to the Diploptera. Since in fossil insects the venation of the wings is often much better preserved than the other parts, one is fully justified in using them to the utmost. The value of such work. however, depends entirely upon the reliability of venational characters among the living members of the particular group to which the fossil supposedly belongs.

Fossils referred by various authors to the Diploptera have been found in Europe in the Tertiary of Chaumerac, France, in the Prussian amber (probably Lower Oligocene), in the Lower Oligocene of Aix in Provence, in the Oligocene of the Isle of Wight, England, in the Lower Miocene of Rodoboj in Croatia, in the Miocene of Parschlug in Steiermark, and in the Upper Miocene of Oeningen in Baden. In North America all the specimens described thus far as Diploptera have been obtained in the (supposedly) Miocene 
shales of Florissant, Colorado. For many of these fossils the characters mentioned in the descriptions are such that their correct placing among the folded-winged wasps is extremely uncertain.

At the Museum of Comparative Zoology of Harvard University I have carefully studied types (or cotypes) of five of the ten species described by Cockerell from Florissant and placed by him in this group.

Of Palrovespa gillettei Cockerell (1906, Bull. Mus. Comp. Zool., L, 2, p. 55) I have seen five specimens. They are in such a condition that the true family, subfamily and generic characters used in the Vespidæ (such as the structure of the eyes, clypeus and thorax, and the number of tibial spurs) cannot be made out. In some of the specimens the fore wing appears to be plaited and, where details of the venation can be traced, they agree perhaps better with those of certain species of Vespa than with those of any other genus of living Hymenoptera. The marginal cell is decidedly pointed at the apex, which lies close to the costal margin; the first discoidal cell is much longer than the submedian; the basal vein joins the subcosta a fair distance from the broad stigma (about as in the living Vespa carolina Linnæus; but this feature of the wing varies considerably within the genus Vespa) ; the two recurrent veins enter the second cubital cell rather farther apart than is usual in Vespa (although $V$. carolina differs less in this respect from many Polistes than most other species of the genus). The hind wing is not visible in any of the specimens. None of the characters indicated above are, however, decisive in tracing the probable affinities of Palxovespa. If one examines an extensive collection of Polistes and Vespa, he soon realizes the futility of attempting to define these genera upon the venation of the fore wing. As a matter of fact, the fore wing of Vespa carolina can well be matched in the genus Polistes, while it differs in several important particulars from that of certain other species of Vespa ( $V$. crabro Linnæus, for example). Nor can the possibility be wholly eliminated that Palæovespa might be rather related to the subfamily Polybiinæ, which contains in the living fauna several genera with a broad (not stalk- 
like) first abdominal segment and a venation very similar to that of the fossils here under discussion. To judge from the specimens I have seen, at any rate, I can only conclude that Palæovespa gillettei is probably a diplopterous wasp and that it most likely belongs in one of the subfamilies of social genera. I have also examined a specimen of $P$. florissantia Cockerell and of $P$. scudderi Cockerell, both very poorly preserved.

The one specimen I have seen of Odynerus præsepultus Cockerell (1906, Bull. Mus. Comp. Zool., L, 2, p. 57) is not sufficiently well preserved to allow of its being placed without reservations among the Diploptera. So far as I can make out, the first discoidal cell is not longer than the submedian and there is no clear evidence that the wings were plaited. This fossil might equally well be a fossorial wasp.

I feel quite positive, on the other hand, that Odynerus palæophilus Cockerell (1906, loc. cit., p. 56) is not one of the Diploptera. The triangular shape of the high marginal cell and the short first discoidal cell would be a unique combination in that group, while it reminds one strongly of some of the parasitic Hymenoptera. Professor Brues, to whom I have shown this fossil, shares my opinion, and has suggested that it might be related to the Aulacidæ. The wing, it is true, appears to be plaited, but one cannot be sure that this is not due to one of the hazards of fossilization. Moreover, the longitudinal plaiting of the fore wing is not in itself sufficient to place a hymenopterous insect in the Diploptera, as this character occasionally occurs in other groups (Leucospinæ, Gasteruptionidæ, Galesus). I have recently taken in Yucatan one of the Psammocharidæ in which the fore wings are distinctly folded longitudinally when at rest.

From the evidence at hand, it is probably safe to conclude that the Diploptera as a group had become differentiated from the other Aculeates before or at the beginning of Miocene times. Cockerell's statement, however, that "the indications are that we must go to the Eocene or even to the Cretaceous, to find the beginning of most of the modern genera of wasps" (1910, Schrift. Phys.-Oekon. Ges. Königsberg, L, p. 1), seems to the writer hardly warranted by the facts. 
C. H. Hicks' paper entitled "Pseudomasaris edwardsii Cresson, another pollen-provisioning wasp, with further notes on $P$. vespoides (Cresson)" (1929, Canad. Entom., LXI, pp. 121-125) is an extremely valuable contribution to our scant knowledge of masarid biology. The author was fortunate in discovering in California the nests of $P$. edwardsii: they are built of clay and attached to rocks, often filling depressions in them, the number of cells per nest varying from one to ten. Pollen masses were found stored in the cells of some of the nests. Hicks also bred a number of parasites from these nests: a mutillid of the genus Photopsis, a chrysid (Chrysis densa Cresson), and some chalcids which may have been hyperparasites. According to Timberlake, P. edwardsii is common at Riverside, California, during May when it visits the flowers of Phacelia.

The same paper contains an interesting observation of the mating of $P$. vespoides, made in Colorado on May 29, 1927. "A male, after sipping nectar from the flowers or going for a short flight, had a habit of returning to a rock close to the ground and resting on its surface in the sun. Before alighting he would hover above the spot, then alight and remain with wings outstretched, nearly but not quite at right angles to his body. At $11.45 \mathrm{~A}$. M. this male was found copulating with a female on a flower of Pentstemon acuminatus. The female was in position for obtaining nectar; the male upon her with his antennæ bent forward and gently tapping her with them on the front of her thorax. Her fore legs were folded, her wings lightly to the side and her abdomen somewhat elevated. Soon there was considerable buzzing. It could be seen that the two were in copula and after 15 seconds of intense buzzing, both flew away. The female soon returned to collect while the male flew again to his rock." Females and males were sometimes found resting in the corolla of Pentstemon, when the weather was cloudy or rainy or in the evening. In Colorado $P$. vespoides visited almost exclusively Pentstemon acuminatus, while in California the same species was found on Pentstemon heterophyllus.

These observations on Pseudomasaris confirm what I have written concerning the anthophilous habits of the Masaridinæ. 

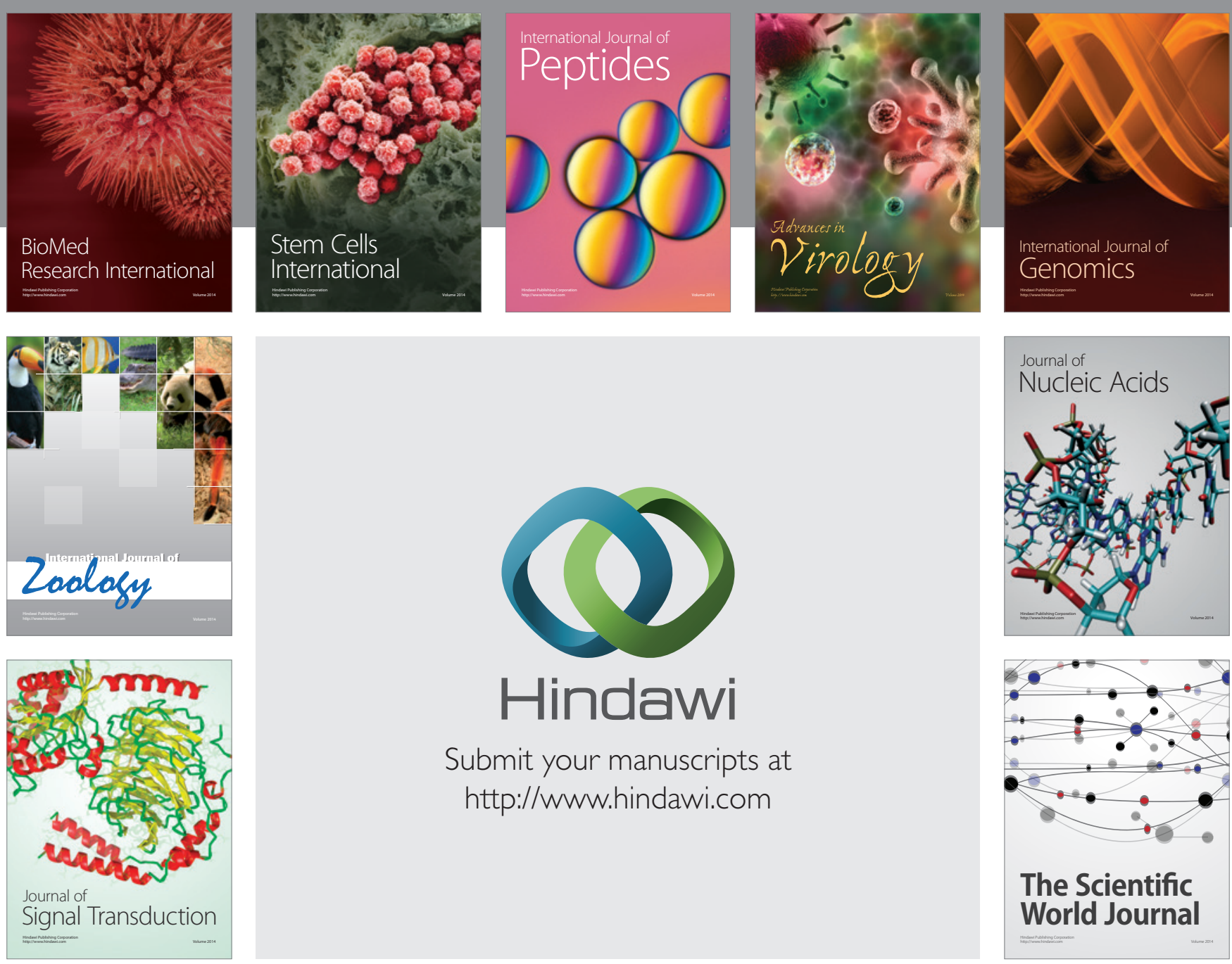

Submit your manuscripts at

http://www.hindawi.com
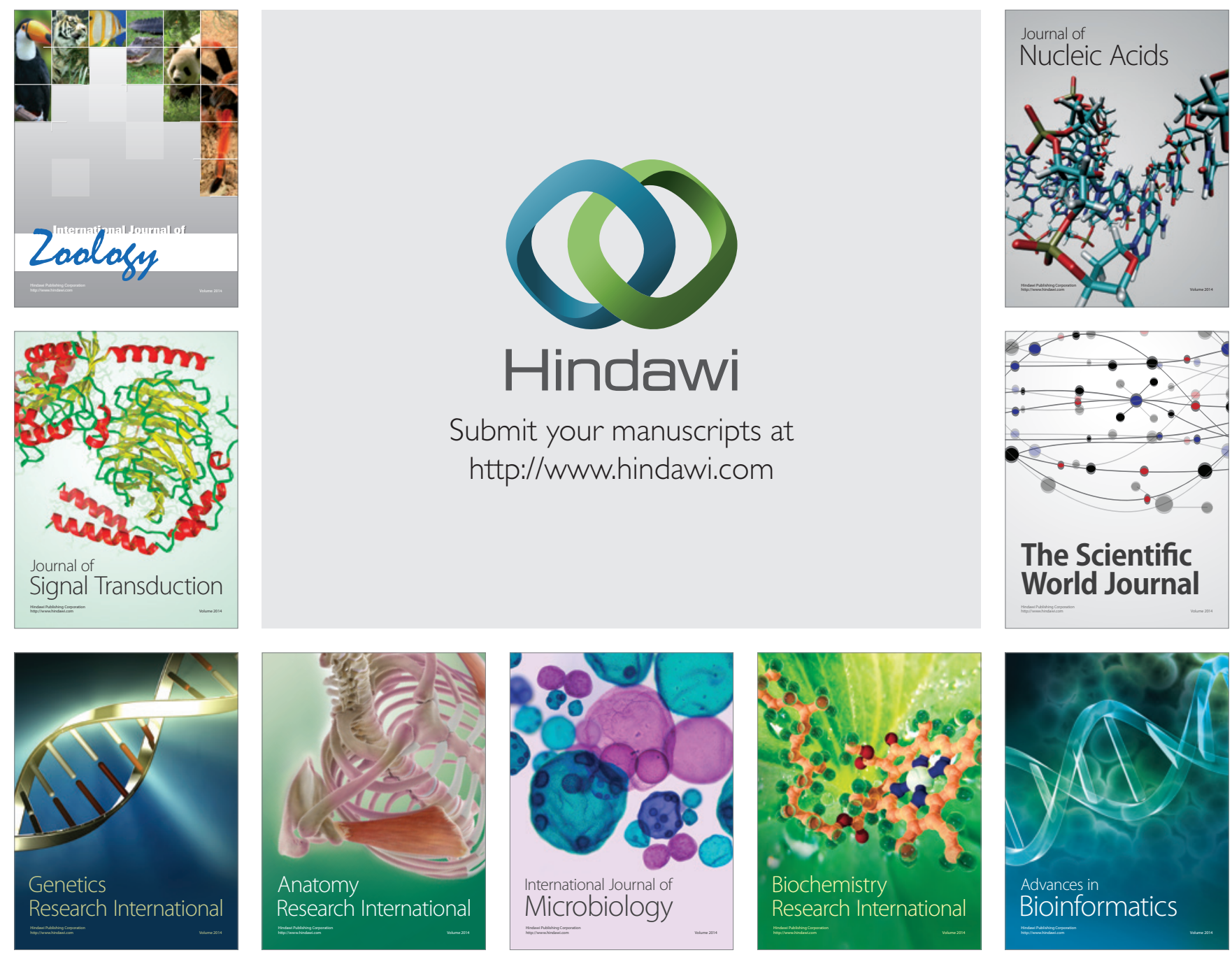

The Scientific World Journal
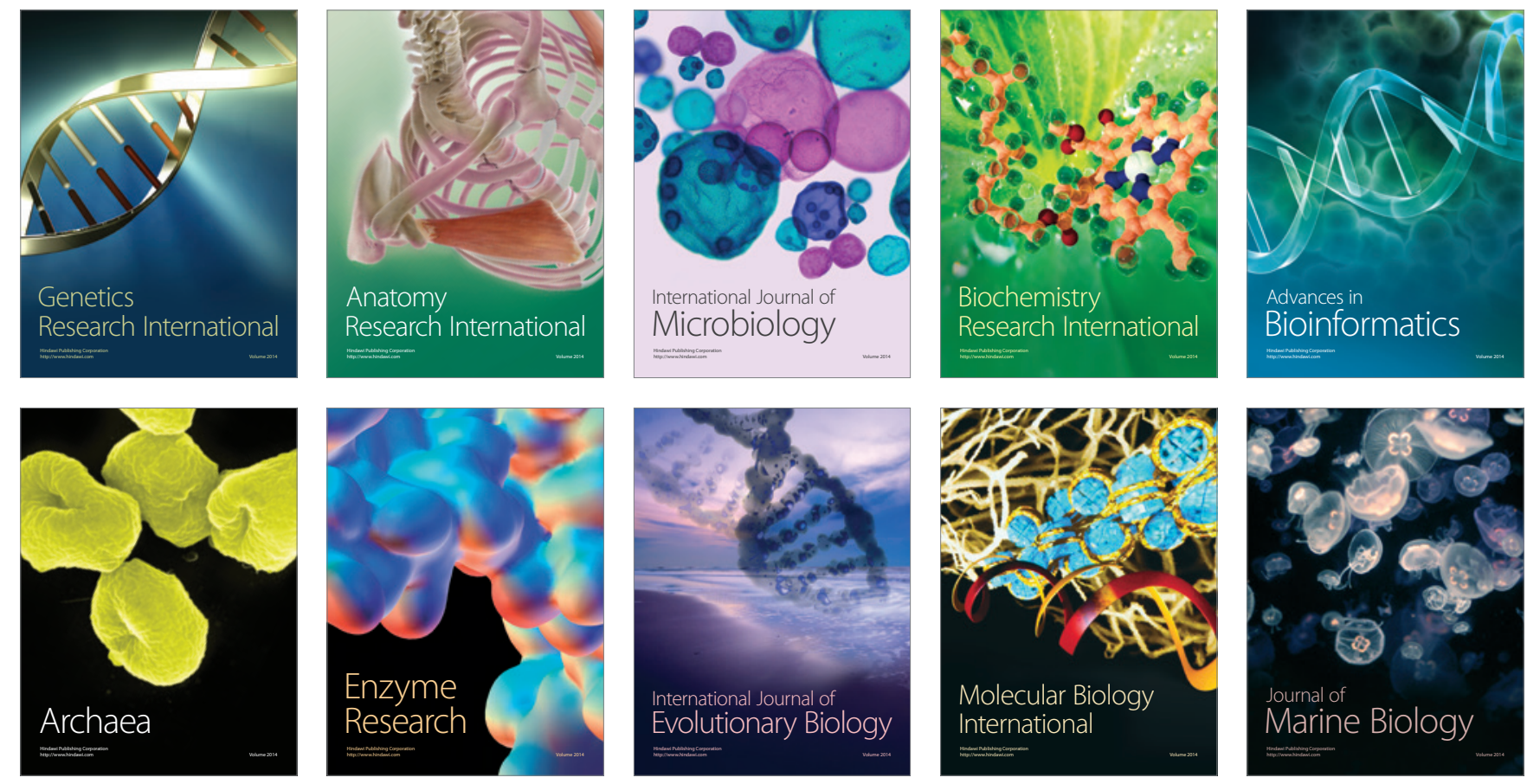